\title{
ArcheoSciences
}

Revue d'archéométrie

$34 \mid 2010$

Varia

\section{Identification of Theophrastus' pigments egyptios yanos and psimythion from archaeological excavations}

A case study

Identification des pigments Theophraste egyptios kyanos et psimythion issus

de fouilles archéologiques : une étude de cas

T. Katsaros, loannis Liritzis and N. Laskaris

\section{OpenEdition}

\section{Electronic version}

URL: https://journals.openedition.org/archeosciences/2632

DOI: 10.4000/archeosciences.2632

ISSN: 2104-3728

\section{Publisher}

Presses universitaires de Rennes

\section{Printed version}

Date of publication: 10 April 2010

Number of pages: $69-80$

ISBN: 978-2-7535-1407-2

ISSN: 1960-1360

\section{Electronic reference}

T. Katsaros, Ioannis Liritzis and N. Laskaris, "Identification of Theophrastus' pigments egyptios yanos and psimythion from archaeological excavations", ArcheoSciences [Online], 34 | 2010, Online since 11 April 2013, connection on 31 January 2022. URL: http://journals.openedition.org/archeosciences/ 2632 ; DOI: https://doi.org/10.4000/archeosciences.2632 


\title{
Identification of Theophrastus' pigments egyptios kyanos and psimythion from archaeological excavations: A case study
}

\author{
Identification des pigments Theophraste egyptios kyanos et psimythion \\ issus de fouilles archéologiques: une étude de cas
}

\author{
T. Katsaros*, I. Liritzis* and N. Laskaris*
}

\begin{abstract}
Following $4^{\text {th }}$ c. B.C. Theophrastus treatise On Stones, regarding preparation of pigments, blue and white ones coming from fresh archaeological excavations in Attica, Greece, a blue made by Kremer factory and a white reproduced following ancient recipe were all submitted to analytical measurements. New results derived from the application of Infrared Photoacoustic Spectroscopy (IRPAS), Scanning Electron X Ray Microprobe Analyser (SEM-EDS), X-Ray Diffraction (XRD) and Raman spectroscopy identified their mineralogical content. The Theophrastus' "psimythion" and "kyanos egyptios" are attributed to the lead white (cerussite and hydrocerussite) and the Egyptian blue (cuprorivaite) respectively.

Résumé : Suivant le traité "Des Pierres " de Théophraste, IV siècle BC, à propos de la préparation des pigments, un pigment blanc et un bleu provenant de fouilles archéologiques récentes en Attique, un bleu fabriqué par le laboratoire Kremer et un blanc reproduit selon une ancienne recette ont été soumis à des analyses physiques. La spectroscopie photoacoustique infrarouge (IRPAS), l'analyse par microscopie électronique à balayage et spectroscopie à dispersion d'énergie (SEM-EDS) et la spectroscopie Raman ont permis d'identifier leur composition minéralogique. Les Théophraste psimythion et kyanos egyptios sont respectivement attribués au blanc de plomb (cérusite et hydrocérusite) et au bleu égyptien (cuprorivaite).
\end{abstract}

Key words: Egyptian blue, lead white, Attica, Theophrastus, IRPAS, XRD, Raman, SEM, pigments.

Mots clé : Bleu égyptien, blanc de plomb, Attique, Theophraste, IRPAS, Raman, SEM, pigments.

\section{INTRODUCTION}

Pigment analysis by modern instrumentation and physical techniques is a routine practice for the study of ancient painting techniques and pigment preparation (Perdikatsis et al., 2000; Berrie, 2007; Tiverios \& Tsiafakis [eds], 2002; Riederer, 1997). A variety of spectroscopy methods have applied, such as, X ray Diffraction (XRD), Raman, Infrared Fourier transform (FTIR), Scanning electron microscope
(SEM) with X-ray microprobe analyzer (EDS), Laser, mass spectrometry, to mention but a few (Kakouli, 2002; Liritzis and Polychroniadou, 2007; Feller, 1986; Bruni et al., 1999; Pagès-Camagna, 1999; Calamiotou et al., 1983; Fillipakis et al., 1979; Janssens and Van Grieken [eds], 2004; Gettens and Stout, 1966; Lautie, 2001; Tite et al., 1982; Fotakis et al., 2007).

The importance of such analyses on cultural heritage materials related to pigments is the identification and char-

* University of the Aegean, Laboratory of Archaeometry, Dept. of Mediterranean Studies - 1 Demokratias Ave., Rhodes 85100, Greece. 
acterization of pigments and raw materials, the production techniques, the palette of ancient painters, and the provenance of the minerals for pigment preparation.

However, of particular value is also the acquisition of pigments via reproduction with simulation experiments, following ancient recipes, and their attribution to ancient sources. Along these issues the present application note aims at the investigation of two powdered samples of blue and white colors coming from Attica (Kifissia and Kerameikos), Greece, providing a detailed analytical account. Though small the number of samples analysed, their importance of characterization lies a) in their archaeological value, b) the further verification of respective pigments and production techniques according to ancient Theophrastus recipe, and c) the application of many analytical techniques including for first time the IRPAS. Earlier work by Katsaros and Bassiakos (2002) recognized the mineral composition related to pigments of geological materials by XRD and SEM obtained from some locations (different from present ones) referred to by Theophrastus.

\section{Historical background}

Theophrastus born in Eressos of Lesvos Island (372-286 B.C.) is considered the founding father of Mineralogy, student and partly successor of Aristotle. He was the first who described a variety of minerals with scientific criteria and referred to their use.

His work is away from metaphysics, for this reason he was a pure materialist philosopher. His book On Stones (De Lapidus) was written on 315 B.C. and considered a handbook of Mineralogy and Petrology. The nature and preparation of the Egyptian Blue (egyptios kyanos in his wording) (see, Lucas and Harris, 1962; Tite et al., 1987; Riederer, 1997; Hatton et al., 2008; Pages-Camagna et al., 1999) and the recipe for Lead White (psimythion in his wording) is described in the following extracts of his On Stones (Eichholz, 1965; Caley and Richards, 1956).

Theophrastus of Eressos, De Lapidus, chapter 55 (line 1-12), about the blue: "[...] Just as there is a natural and an artificial red ochre, so there is a native kyanos and a manufactured kind, such as the one in Egypt. There are three kinds of kyanos the Egyptian, the Scythian, and the Cyprian. The Egyptian is the best for making pure pigments, the Scythian for those that are more dilute. The Egyptian variety is manufactured, and those who write the history of the kings of Egypt state which king it was who first made fused kyanos in imitation of the natural kind; and they add that kyanos was sent as tribute from Phoenicia and as gifts from other quarters, and some of it was natural and some had been produced by fire. Those who grind coloring materials say that kyanos itself makes four colours; the first is formed of the finest particles and is very pale, and the second consists of the largest ones and is very dark. These are prepared artificially."

Theophrastus of Eressos, De Lapidus, chapter 56 (line 1-5), chapter 57 (line 1), about the white: "[...] and so is white lead. Lead about the size of a brick is placed in jars over vinegar, and when this acquires a thick mass, which it generally does in ten days, then the jars are opened and a kind of mold is scraped off the lead, and this is done again until it is all used up. The part that is scraped off is ground in a mortar and decanted frequently, and what is finally left at the bottom is white lead."

The report of Theophrastus on fired Kyanus (the Egyptian Blue) is important because it provides information concerning its production, to imitate the native stone (Lapis Lazuli). The colour produced can be separated into four hues of blue from the darker to the brighter according to grain size. In accordance to the text the method was well known among the people who made the drugs (probably for the court of the Egyptian Pharaohs) and in Thera (Perdikatsis et al., 2000).

The recipe on the preparation of Lead White is the most ancient written Greek source, while the synthesis of the Egyptian blue or Kyanos is the oldest from the $3^{\text {rd }}$ millennium B.C. (see Tite et al., 1987; Delamare, 2007; Riederer, 1997) and was followed by Dioscorides, Vitruvius (Vitruvio, De re architectura, vol VII, Loeb Clasical Library, MCMLXXXV), Pliny (Natural History, 35 ${ }^{\text {th }}$ Book, The Loeb Classical Library, W. Heinemann Ltd., Cambridge MA, 1958-1966), and Pliny the Elder (Historiae Naturalis Libri, vol.5, XXXI-CXXXV, Teubner, Lipsiae, 1897). On the other hand it was incomplete, because of the lack of the exact description of the jar and its cover. We have synthesised the recipe from the text of Dioscorides Materia Medica $V$. Both of the two texts describe a complete method for Lead White preparation.

\section{SAMPLES AND SAMPLE PREPARATION}

Two blue (EGY-1, EGY-2) and two white (KER-1, PSI-1) pigments are analysed. The two archaeological samples, both of the $4^{\text {th }}$ c. B.C., are,

a) a blue powder (EGY-1) from a Hellenistic graveyard of a rescue excavation of Kifissia municipality of Attica, north of Athens. Sampling was made of 2 grams out of total powder of around 10 grams that was found inside a ceramic vessel, and, 
b) a white powder (KER-1) of a round tablet $2.5 \mathrm{~cm}$ diameter and $-0.5 \mathrm{~cm}$ thick, from an actor's tomb at Kerameikos below Athens Acropolis, northern side. About a dozen of pellets were found inside the lekanis ceramic vessel shielded with a cover (today exposed in the Museum of Kerameikos). The tomb is dated in the $4^{\text {th }}$ century B.C. that is contemporary to Theophrastus' work On Stones. Consequently this finding is considered significant because it provides clues on its manufacture from metallic lead after exposure in vinegar steam. We attribute this to psimythion used by actors to dye their faces white or their body, to imitate female characters in the theatrical play.

The other two are contemporary ones, the blue one is a commercial from Kremer Co (10060 no of Kremer's catalogue, given as $\mathrm{CaCuSi}_{4} \mathrm{O}_{10}$ ), Germany (EGY-2), and the white was made in our laboratory from metallic lead (PSI-1).

\section{REPRODUCTION OF PSIMYTHION}

Sample PSI-1 is the reproduced in laboratory white powder following Theophrastus ancient recipe On Stones. (ref. On Stones $\$ 56$ above). Ccommercial metallic lead cut in the shape of a brick approx. $10 \mathrm{~cm}$ length by $5 \mathrm{~cm}$ width and $2 \mathrm{~cm}$ thickness, hanged over within a ceramic vessel where on its bottom vinegar was placed. The vessel was covered by a thin skin about $1 \mathrm{~mm}$ which is quasi-transparent to air (i.e. it breaths) (see, fig. 8). Following this shield it was placed under the sun (on average $30^{\circ} \mathrm{C}$ with a range $27-55$ degrees) for 10 days. Then the skin cover was removed and the lead brick taken out. A white powdered layer on its surface was removed by scratch, then washed in a marble mortar and ground down with marble pestle to a fine powder, following a dry out under the sun. Subsequently it was applied on a prepared wooden surface with a gypsum or calcite support.

\section{Analytical techniQues}

The analytical methods used are XRD, SEM (EDS), Raman, and for first time IRPAS. These were chosen to answer certain questions regarding mineralogy, molecular structures, absorption bands and vibration modes and aid the comparison between the obtained data with available data banks per technique. This multiscientific approach increases reliability and serves as a double checking tests of pigment identification, while they provide some clues regarding analytical sensitivities and additional peak information. For example, in the case of Raman and IRPAS, the symmetric vibrations give strong spectral lines and the asymmetric weak and very weak, and also, due to the rule of mutual exclusion absorption molecules do not provide clear peaks. Thus, with a symmetric molecule active vibrations in the Raman are inactive in the IR and vice versa, while for molecules without centre of symmetry vibrations may be inactive in both modes. Thus, their comparison may provide useful data about the symmetry of a molecule and the provision of clearer peaks there where one of them may not

For all techniques sample preparation followed standard procedure:

\section{XRD}

For XRD (Siemens D500, defocusing Bragg-Brentano, $\mathrm{Cu}$ Ka X ray, supplied with secondary graphite monochromator) the sample was ground down to less than 10 microns following standard procedures and spectra obtained per 4 sec per step from $10-90^{\circ}$, and use of software EVA and peak identification through Jade X-ray Diffraction patterns standards was made.

\section{SEM}

Compositional analyses were performed using a scanning electron microscope (Philips FEI-Quanta INSPECT) equipped with an energy dispersive spectrometer (EDS) System PV7760 with an SUTW detector and use of a correction programme ZAF (correction \% Quantity qualification). All analyses were performed at $25 \mathrm{kV}$, with a take-off angle of $35^{\circ}$. The detection limit is in the range of tens of ppm, but major and minor elements below $0.1 \%$ are not considered reliable, and errors are around 5\%. The powdered sample was compressed in pellets. Values are average of three bulk measurements along with standard deviation, and the focused area was $1 \times 1 \mathrm{~mm}^{2}$.

\section{RAMAN}

For Raman a portable Rockhound of Deltanu was used, with frequency scan width between 200 to $2000 \mathrm{~cm}^{-1}$, resolution $8 \mathrm{~cm}^{-1}$, standards ASTM Raman shift frequency standards (ASTM E 1840) and, analytical beam focus $35 \mathrm{~nm}$ for eight repeats on various chosen points on the sample, and spectral processing through TableCurve2D software.

\section{Infrared Photoacoustic Spectroscopy (IRPAS)}

IRPAS was applied on the initial bulk powder. As it was used for first time the rules of operation are discussed below in brief. 
In this technique, a sample less than $10 \mathrm{~mm}$ in diameter is placed in a helium-filled chamber equipped with a high sensitivity microphone. The specimen absorbs the infrared radiation and undergoes an oscillatory heating and becomes a source of thermal waves. The waves within the bulk sample propagate to the surface and into the helium atmosphere. The photoacoustic signal is generated at the surface and is caused by the thermal expansion of the gas (McClelland et al. 1993). The magnitude of the signal varies in proportion to the concentration of the water species. The absorbance values are calculated from integrated peak areas. Each absorbance value represents an averaged measure for the entire surface of the sample exposed to the $5 \mathrm{~mm}$ diameter infrared beam. IR-PAS will be used to measure the concentration of diffused water in the hydrated archaeological layers with a MTEC 300 photoacoustic cell accessory for a Bomem MB-120 spectrometer. Each sample will be run at a resolution of 8 wave numbers for 256 scans. Carbon black, supplied by the manufacturer, is used to establish the background conditions for the instrument.

Basic advantages of IRPAS with respect to other IR / spectroscopy techniques are the high sensitivity consequently measurements of large precision and low detection limits (ppb or ppt), the simultaneous analysis of small sized samples, and the great stability.

\section{Results AND Discussion}

Archaeological samples were first submitted to SEM analysis which lead us to the further application of the other techniques. For this reason no investigation of blind tests with other pigments of same colour was attempted.

Fig. $1(\mathrm{a}, \mathrm{b})$ and fig. $2(\mathrm{a}, \mathrm{b})$ shows the diffraction spectra for blue and white, fig. 3 (a, b) and Fig. 4 (a, b) show the Raman spectra for blue and white respectively, Table 1 and table 2 give the chemical contents with SEM/EDS, and fig.5 (a, b) and fig.6 (a, b) provide the infrared absorption spectra (IR-PAS). Fig 7 shows the sampling from the white material in the Kerameikos Museum (Athens, Greece) and Fig. 8 the reconstruction of the apparatus which described by Theophrastus for psimythion production. It should be noted that the present reproduction experiment is a repeat of an earlier preliminary attempt (Katsaros and Bassiakos 2002), where the newer sample shows similar characteristics to the earlier one which reinforces the reliability of the obtained result.

Analytically the results per sample are discussed below.

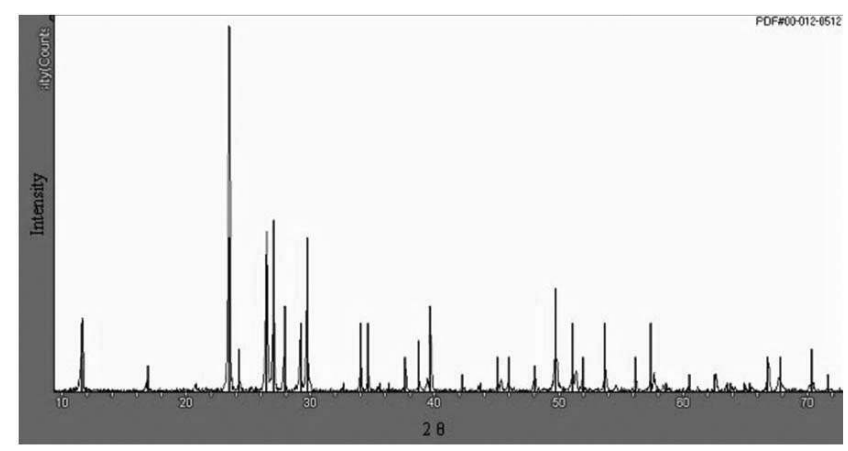

Figure 1a: X-ray Diffraction spectrum of sample EGY-2. Synthetic Cuprorivaite $\left(\mathrm{CuCaSi}_{4} \mathrm{O}_{10}\right)$ from Kremer Laboratory (Germany), a modern re-production of the Egyptian Blue. Reference number at Jade program is 15-512.

Figure 1a: Spectre de diffraction $X$ de l'échantillon EGY-2. Cuprorivaite synthétique du laboratoire Kremer (Allemagne), une reproduction moderne du bleu égyptien. Numéro de référence du programme Jade : 15-512.

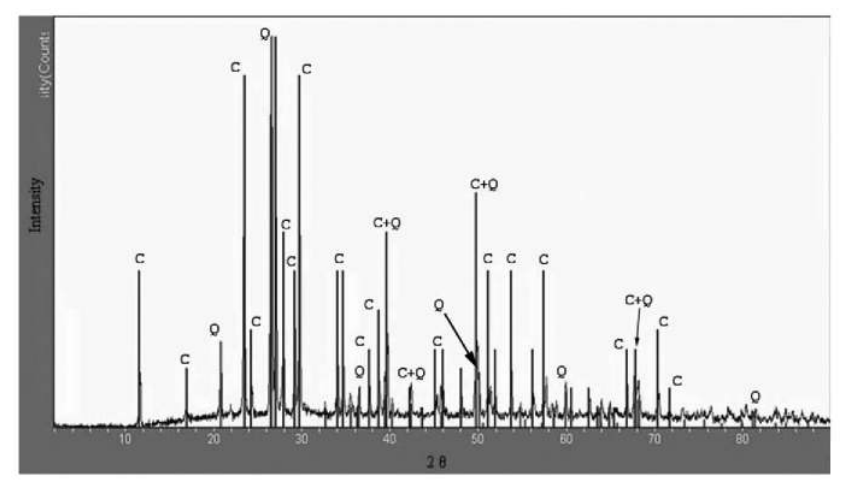

Figure 1b : X-ray Diffraction spectrum of sample EGY-1. Sample of the blue agglomerate powder from graveyard at Kifissia Excavation of 4th cent. B.C. identified as Cuprorivaite and Quartz synthetic. C: Cuprorivaite, Q: Quartz

Figure 1b: Spectre de diffraction X de l'échantillon EGY-1. Echantillon d'un agglomérat de poudre bleue provenant de la fouille du cimetière de Kifissia, du IV siècle BC: composé de Cuprorivaite et de quartz synthétique. C: Cuprorivaite, Q: Quartz.

\section{Blue pigment-EGY-1}

The blue pigment EGY-1 from Kifissia, contemporaneous to Theophrastus is identified as cuprorivaite identified with Egyptian blue (cuprorivaite, $\mathrm{CaCuSi}_{4} \mathrm{O}_{10}$ ). (Calamiotou et al., 1983) (figs. 1a, 1b, 3a, 3b, 6a, 6b and table 1). The chemical substance of the Egyptian Blue has many differences across the period 3000 B.C.-500 A.D., as well as the place of its preparation. In all cases the main phase is cuprorivaite, the responsible mineral for the characteristic blue color (see, e.g. 


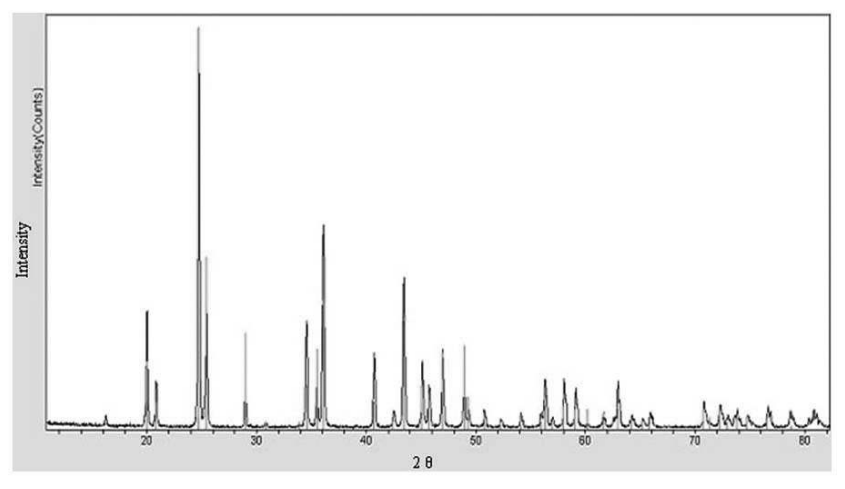

Figure 2a: X ray Diffraction spectrum of sample KER-1 Sample. White powder from the tablet of Kerameikos Museum, identified as the mineral Cerussite (5-0417 2 $\mathrm{PbCO}_{3}$ Cerussite). Reference number at Jade program is 5-0417.

Figure 2a: Spectre de diffraction X de l'échantillon KER-1. Poudre blanche provenant de la pastille du Musée Kerameikos, composé de Cérusite (5-0417 2PbCO 3 Cerussite). Numéro de référence du programme Jade : 5-0417.

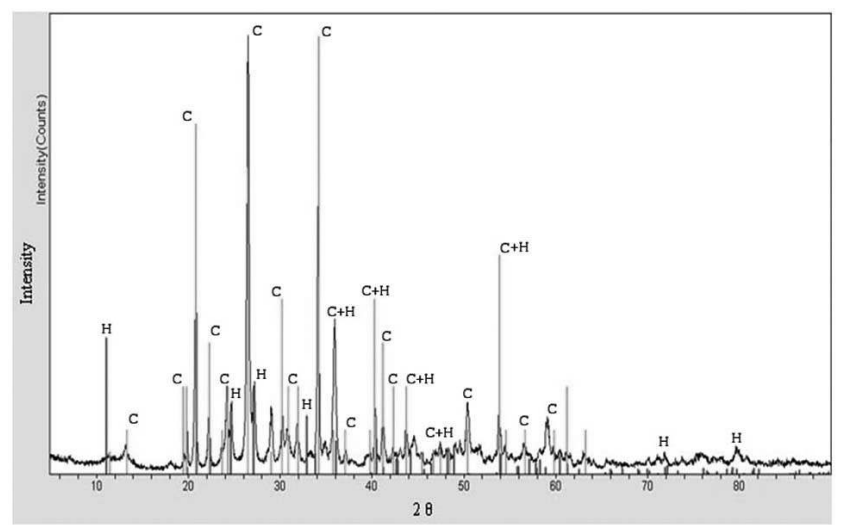

Figure 2b: X-ray Diffraction spectrum of sample PSI-1. Experimental reproduction of the Theophrastus' "psimythion" identified as Crussite and Hydrocerussite, the two components of Lead White. C: Cerussite, H: Hydrocerussite.

Figure 2b: Spectre de diffraction $X$ de l'échantillon PSI-1. Reproduction expérimentale du Théophraste "psimythion" composé de Crussite et d'Hydrocérusite. Les deux composants du Blanc de plomb. C: Cerussite, H: Hydrocerussite.

Jaksch et al., 1983; Tite et al., 1987; Riederer, 1993, 1997; Delamare, 2007; Hatton et al., 2008). Conclusively, it contains glassy phase, the crystalline silica phase, cuprorivaite and other compounds such as $\mathrm{Zn}, \mathrm{Pb}$ etc.

The characteristic Raman wavelengths are the main intense ones at 430,465, $1086 \mathrm{~cm}^{-1}$, with minor ones at -580 and $-790 \mathrm{~cm}^{-1}$ (Lautie, 2001).

The Raman spectra of fig. 3a, b (see e.g. Pages-Camagna et al., 1999; 2003a, b).are obtained without filtering thus

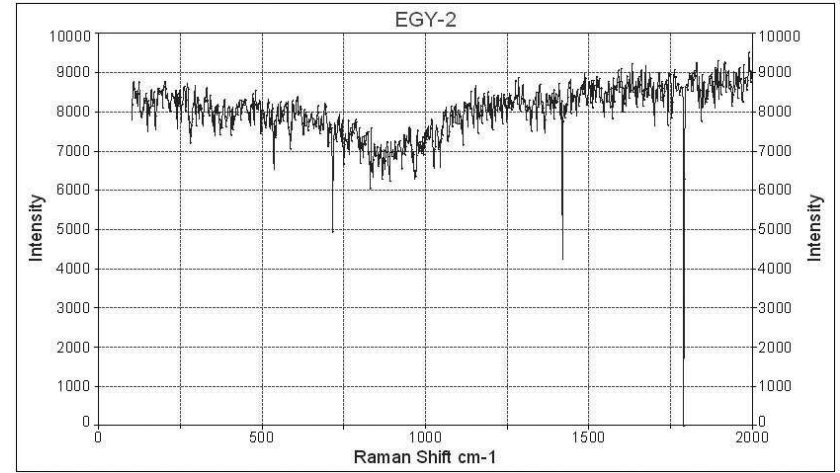

Figure 3a: Raman spectrum of sample EGY-2. Modern reproduction of the Egyptian blue from Kremer laboratory (Germany), is dominated by the phase of Cuprorivaite.

Figure 3a: Spectre Raman de l'échantillon EGY-2. Reproduction moderne du bleu égyptien.

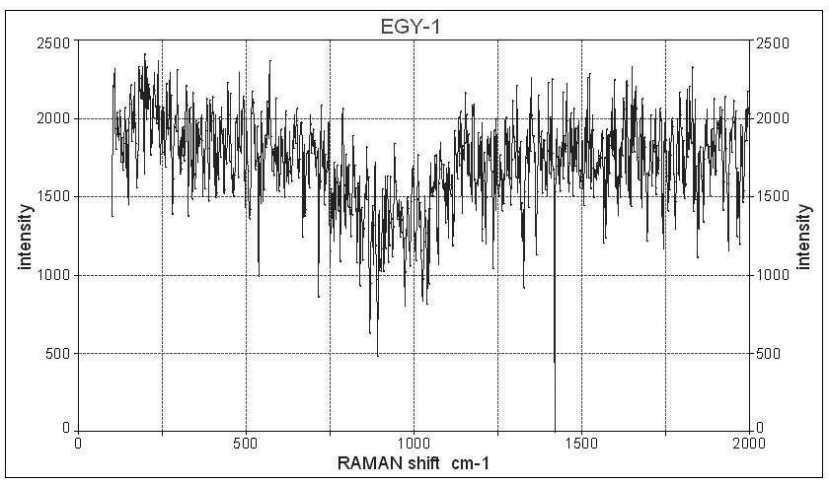

Figure 3b: Raman spectrum of sample EGY-1. Archaeological material from the excavation at Kifissia (Attica, Greece). Blue powder from a Hellenistic cemetery of $4^{\text {th }}$ cent. B.C. identified as the Egyptian blue.

Figure 3b: Spectre Raman de l'échantillon EGY-1. Materiel archéologique de la fouille de Kifissia (Attique, Grèce). Poudre bleue provenant du cimetière Hellénistique du $I V^{e}$ siècle BC, identifiée comme du bleu égyptien.

the noisy picture. As a result some of the identified peaks in table 3a inhere an broad peak amplitude of around $15 \mathrm{~cm}^{-1}$. The IRPAS spectra provide another potential for pigment identification. Indeed, from fig. $5(\mathrm{a}, \mathrm{b})$ the Egyptian blue is easily identified giving absorption peaks at 979, 1033, 1157, $1604,1982 \mathrm{~cm}^{-1}$. Table 3 gives the characteristic peaks of Raman and IRPAS spectra in comparison to the data from bibliography of Raman peaks both for lead white and the Egyptian blue. (for FTIR see Bruni et al., 1999; Edreira et al., 2003)

Microanalysis (EDS) of the blue color of Kifissia has revealed the presence of $\mathrm{Zn}$ (table 1, EGY-1), quite unusual 


$\begin{array}{ccc}\begin{array}{c}\text { Elements by } \\ \text { oxides \% Wt. }\end{array} & \begin{array}{c}\text { EGY-1 } \\ \text { Egyptian blue from Kifissia } \\ \text { (ancient) }\end{array} & \begin{array}{c}\text { EGY-2 } \\ \text { Egyptian blue from } \\ \text { Kremer Co.(modern). }\end{array} \\ \mathrm{NaO} & 3,2 \pm 0.13 & 4,1 \pm 0.16 \\ \mathrm{MgO} & 0,4 \pm 0.02 & \mathrm{Nd} \\ \mathrm{Al}_{2} \mathrm{O}_{3} & 3,3 \pm 0.13 & 0,8 \pm 0.03 \\ \mathrm{SiO}_{2} & 63,3 \pm 2.53 & 56,6 \pm 2.26^{*} \\ \mathrm{P}_{2} \mathrm{O}_{5} & 0,3 \pm 0.018 & \mathrm{Nd} \\ \mathrm{K}_{2} \mathrm{O} & 0,3 \pm 0.018 & \mathrm{Nd} \\ \mathrm{CaO} & 8,5 \pm 0.34 & 13,3 \pm 0.53 \\ \mathrm{CuO} & 14,3 \pm 0.6 & 25,2 \pm 1 \\ \mathrm{ZnO} & 1,5 \pm 0.06 & \mathrm{Nd} \\ \mathrm{Fe} \mathrm{O}_{3} & 1,2 \pm 0.05 & \mathrm{Nd} \\ \mathrm{PbO} & 3,7 \pm 0.15 & \mathrm{Nd} \\ \mathrm{Total} & 100 & 100\end{array}$

Table 1: SEM/EDS analysis of samples EGY-1 and EGY-2. Note that silica derives from both cuprorivaite (predominate) and quartz. In EGY-2 this represents only cuprorivaite. * The oxides of pure Egyptian blue compound give $\mathrm{SiO}_{2}=63.93 \%, \mathrm{CuO}=21.16 \%$ and $\mathrm{CaO}=14.92 \%$.

Table 1 : Analyse SEM/EDS des échantillons EGY-1 et EGY-2. Notons que la silice dérive à la fois de la Cuprorivaite (prédominante) et du quart. Dans EGY-2, ce ci représente seulement de la Cuprorivaite. Les oxydes de bleu égyptien pur donne $\mathrm{SiO}_{2}=63.93 \%, \mathrm{CuO}=21.16 \%$ and $\mathrm{CaO}=14.92 \%$.

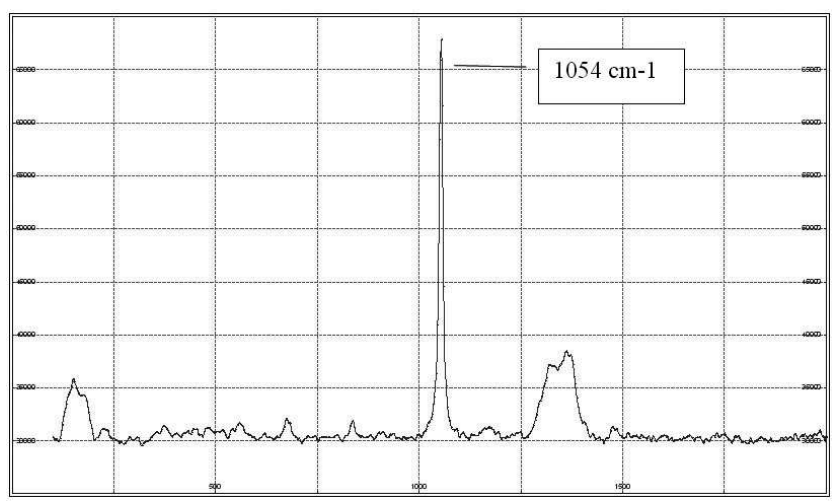

Figure 4a: Raman spectrum of sample KER-1. Raman spectra of white powder from Kerameikos Museum identified as carbonate phase of Lead (Cerussite).

Figure 4a: Spectre Raman de l'échantillon KER-1. Spectre Raman de la poudre blanche provenant du Musée Kerameikos, identifié comme une phase carbonatée de plomb (Cérusite).

for this specific color. According to Filippakis et al. (1979) and Filippakis (1978) it is proposed that $\mathrm{Zn}$ is a sub product from the recycling method of copper alloys. Regarding the $\mathrm{Pb}$ its presence may be related to an unknown raw material containing $\mathrm{Pb}$ and it is a subject of further research. Another point of interest is the silica phase of this ancient color, which is attributed to a glass phase in which the crystals of cuprorivaite have grown. The presence of $\mathrm{NaO}$ in SEM

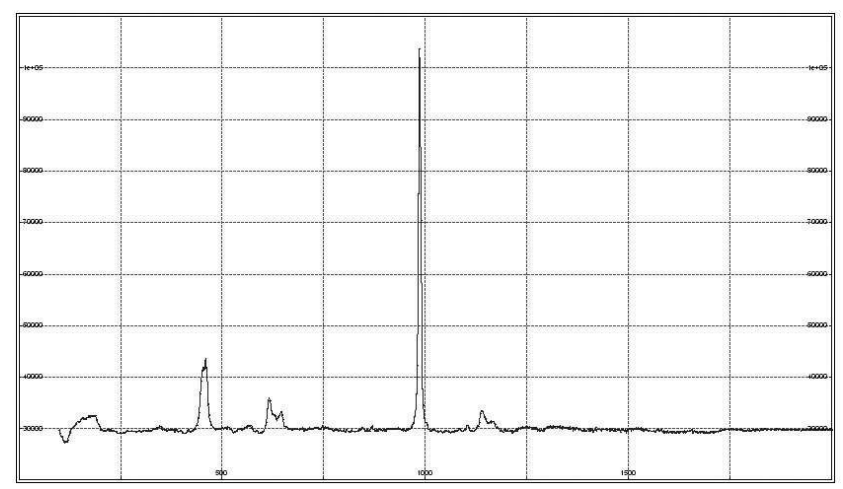

Figure 4b: Raman spectrum of our reproduction of the material psimythion in accordance to Theophrastus' recipe. The sample is identified as carbonate of Lead (Cerussite).

Figure $4 b$ : Spectre Raman de notre reproduction de la substance psimythion en suivant la recette de Théophraste. L'échantillon est identifié comme un carbonate de plomb (Cérusite).

(in traditional powder XRD is below detection limit) may be due to some type of added alkalis used by modern and ancient procedures. The IRPAS spectral difference between the EGY-1 and EGY-2 (figs 5a, 5b) is due to the humidity of the ancient material (water peak at $3000-3500 \mathrm{~cm}^{-1}$ ). Although cuprorivaite can not accept $\mathrm{OH}$ in its lattice and it is stable to weathering, however a DTA analysis has shown presence of water uptake at $-150^{\circ} \mathrm{C}$ which justifies the surprisingly obtained IRPAS water absorption peak. This

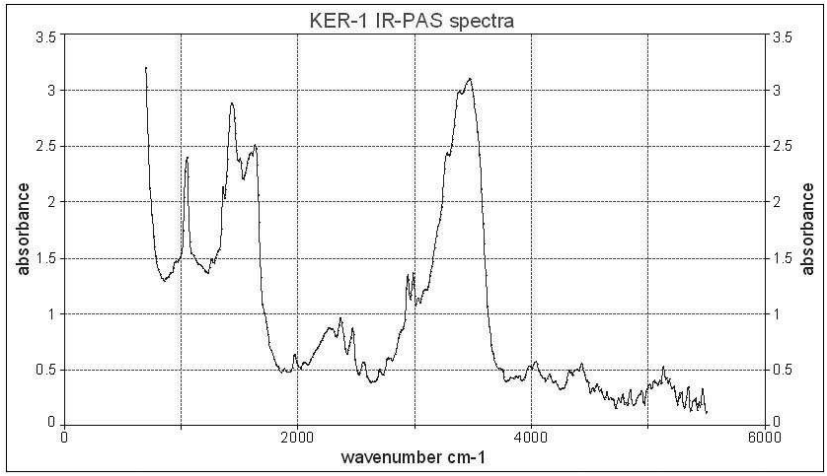

Figure 5a: IR-PAS spectrum of sample KER-1. Archaeological material from Kerameikos Museum, white powder from tablets found in ceramic vessel (lekanis). It was called in antiquity psimythion, the well known lead white pigment.

Figure 5a: Spectre IR-PAS de l'échantillon KER-1. Substance archéologique provenant du Musée Kerameikos, poudre blanche de pastilles retrouvées dans de la vaisselle céramique (lekanis). Elle était appelée psimythion dans l'Antiquité, le fameux pigment blanc. 


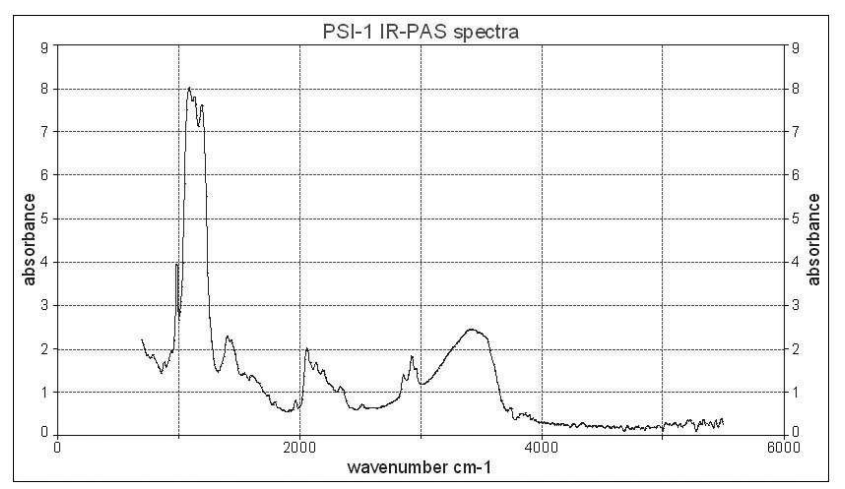

Figure 5b: IR-PAS spectrum of sample PSI-1. Our reproduction of psimythion in accordance to Theophrastus' recipe. Figure 5b: Spectre IR-PAS de l'échantillon PSI-1. Notre reproduction du psimythion.

$\begin{array}{ccc}\begin{array}{c}\text { Elements } \\ \text { by oxides } \\ \% \text { Wt. }\end{array} & \begin{array}{c}\text { KER-1 } \\ \text { Lead White from Kerameikos } \\ \text { Museum }\end{array} & \begin{array}{c}\text { PSI-1 } \\ \text { Lead White } \\ \text { Our reproduction } \\ \text { (Theophrastus' recipe) }\end{array} \\ \mathrm{Al}_{2} \mathrm{O}_{3} & 0.1 \pm 0.02 & \mathrm{Nd} \\ \mathrm{SiO}_{2} & 0.6 \pm 0.024 & \mathrm{Nd} \\ \mathrm{P}_{2} \mathrm{O}_{3} & 1.8 \pm 0.07 & \mathrm{Nd} \\ \mathrm{CaO} & 0.1 \pm 0.02 & \mathrm{Nd} \\ \mathrm{Fe}_{2} \mathrm{O}_{3} & 0.8 \pm 0.032 & \mathrm{Nd} \\ \mathrm{PbO}^{*} & 0.7 \pm 0.03 & \mathrm{Nd} \\ \mathrm{FO}_{2} & 80.02 \pm 4 & -100 \% \\ \text { total } & >0.1 \pm 0.02 & \mathrm{Nd} \\ & 100 \text { (including CO2) } & 100\end{array}$

Table 2: SEM/EDS analysis of samples KER-1 and PSI-1. The presence of $\mathrm{F}$ in the ancient sample KER-1 declare the possible provenance from the Laurium mines at Attica, an well known site for the Lead and Silver production in antiquity. (Dr. Y. Bassiakos, personal communication, 2007). ${ }^{*}$ The lead oxide derives from $\left(\mathrm{PbCO}_{3}\right)$ which is $95.80 \%$. Pure $\mathrm{PbCO}_{3}$ has $\mathrm{PbO}=83.53 \%$, $\mathrm{CO}_{2}=16.47 \%$.

Table 2 : Analyse SEMIEDS des échantillons KER-1 et PSI-1. La présence de $F$ dans l'échantillon ancien KER-1 indique une possible provenance des mines du Laurium en Attique, une site bein connu pour la production de plomb et d'argent dans l'Antiquité (Dr. Y. Bassiakos, communication personnelle, 2007). *'oxyde de plomb dérive du $\left(\mathrm{PbCO}_{3}\right)$ à $95.80 \%$. Le $\mathrm{PbCO}_{3}$ pur possède $83.53 \%$ de $\mathrm{PbO}$ et $16.47 \%$ de $\mathrm{CO}_{2}$.

is rather due to some kind of humidity taken up during burial in the archaeological context. The modern reproduction EGY-2 (from Kremer) is not expected to have same level of $(\mathrm{OH})$ because the material is pure cuprorivaite $(\mathrm{Cu}$. $\left.\mathrm{Ca} . \mathrm{Si}_{4} \mathrm{O}_{10}\right)$.

\section{White pigment KER-1}

From table 1 and fig. 2 and fig. 4 the white pigment (KER-1) from Kerameikos Museum, is identified as Lead White (psimythion), which corresponds to hydrocerussite $\left(\mathrm{Pb}_{3}\left(\mathrm{CO}_{3}\right)_{2}(\mathrm{OH})_{2}\right)$, combining all spectroscopic and diffractive methods employed (see, figs. 2a, 2b, 4a, 4b, 5a, 5b) and Tables 2, 3a, 3b). (see e.g. Welcomme et al., 2006; Perdikatsis et al., 2002). Use of UCL Raman library is made to identify the characteristic peaks for pigments (on internet UCL Raman library of natural and artificial pigments: [www.chem.ucl.ac.uk/resources/raman/index.html], accessed on Oct-Dec 2008) (table 3).

It is important to note here that the experimental reproduction of Theophrastus' psimythion supplied us with a type of hydrocerusite and cerusssite $\left(\mathrm{PbCO}_{3}\right)$ (fig. $2 \mathrm{a}$ and $4 \mathrm{a}, \mathrm{b}$ ). The observed vibration bands at $-829-832$ and $-1050-1054$ $\mathrm{cm}^{-1}$ are the active $v_{1}$ and $v_{2}$ carbonate modes. The small satellite bands at 823 and 1031 on the low-wavenumber side of the fundamental vibrations $v_{2}$ and $v_{1}$ respectively, have been assigned to the isotopic substitutions of ${ }^{13} \mathrm{C}$ and ${ }^{18} \mathrm{O}$. The vibration bands $-660-690 \mathrm{~cm}^{-1}$ are the active $v_{4}$ carbonate bending mode (Martens et al., 2004). Both these minerals make the Lead White. The Raman spectra of fig. $4 \mathrm{a}, \mathrm{b}$ indicate presence of cerussite and hydrocerussite, and the lack of cerussite peak in fig. $4 \mathrm{~b}\left(1050 \mathrm{~cm}^{-1}\right)$ is not conclusive because Raman bands at 949, 966, 989, 1000 and $1104 \mathrm{~cm}-1$ are assigned to combination and overtone bands (Martens et al., 2004).

The ten days duration referred to by Theophrastus is confirmed, accounting for the ambient environment in Eastern Mediterranean where the level of temperature is appropriate to take place the reaction of cerussite' production. On the other hand, the absence of $\mathrm{CO}_{2}$ in the covered clay jar is another issue, which however was encountered with the use of an animal skin cover (figs. 7, 8).

The use of IRPAS in the characterization of lead white and the Egyptian blue (figs 5a, 5b, 6a, 6b) proves effective, providing another technique for the identification of painting powder and pigments. The IRPAS spectra exhibit a difference with the respective spectra of the modern reproduced material (our reproduction of lead white), observed also by XRD (fig. 1a, b and fig. 2a, b). Sample PSI-1 (modern) has a phase of hydrocerussite in addition to pure cerusssite. Sample KER-1 is pure cerussite, therefore the IR spectroscopy described the type of bond of $(\mathrm{OH})$ which has hydrocerussite. 


\begin{tabular}{|c|c|c|c|}
\hline Sample code & $\begin{array}{c}\text { Raman } \\
\text { Peaks, } \mathrm{cm}^{-1} \\
\text { (from refs) }\end{array}$ & $\begin{array}{c}\text { Raman } \\
\text { peaks } \\
\text { obtained, } \\
\text { cm }^{-1}\end{array}$ & $\begin{array}{l}\text { Mineralogy } \\
\text { Description }\end{array}$ \\
\hline \multirow{16}{*}{$\begin{array}{c}\text { EGY-1 } \\
\text { Egyptian-blue } \\
\text { from } \\
\text { Kifissia } \\
4^{\text {th }} \text { B.C. }\end{array}$} & 114 & 117 & \multirow{16}{*}{$\begin{array}{c}\text { Egyptian blue } \\
\text { calcium copper(II) } \\
\text { silicate, } \mathrm{CaCuSi} \mathrm{O}_{10} \\
\text { (bold are silicates. } \\
\text { Some of the } \\
\text { obtained peaks have } \\
\text { a broad amplitude } \\
\text { and spectrum has } \\
\text { increased noise due to } \\
\text { lack of red filtering, } \\
\text { see text.) }\end{array}$} \\
\hline & 137 & 139 & \\
\hline & 200 & 198 & \\
\hline & 230 & 237 & \\
\hline & 358 & 358 & \\
\hline & 377 & 384 & \\
\hline & 430 & 447 & \\
\hline & 475 & 480 & \\
\hline & 571 & 571 & \\
\hline & 597 & 590 & \\
\hline & 762 & 766 & \\
\hline & 789 & 787 & \\
\hline & 992 & 994 & \\
\hline & 1012 & 1013 & \\
\hline & 1040 & 1033 & \\
\hline & 1086 & 1080 & \\
\hline \multirow{16}{*}{$\begin{array}{c}\text { EGY-2 } \\
\text { Egyptian blue } \\
\text { Kremer } \\
\text { (modern) }\end{array}$} & 114 & 124 & \multirow{16}{*}{$\begin{array}{c}\text { Egyptian blue } \\
\text { Calcium copper(II) } \\
\text { silicate, } \mathrm{CaCuSi}_{4} \mathrm{O}_{10}\end{array}$} \\
\hline & 137 & 146 & \\
\hline & 200 & 202 & \\
\hline & 230 & 237 & \\
\hline & 358 & 358 & \\
\hline & 377 & 382 & \\
\hline & 430 & 428 & \\
\hline & 475 & 473 & \\
\hline & 571 & 573 & \\
\hline & 597 & 610 & \\
\hline & 762 & 764 & \\
\hline & 789 & 787 & \\
\hline & 992 & 997 & \\
\hline & 1012 & 1020 & \\
\hline & 1040 & 1035 & \\
\hline & 1086 & 1087 & \\
\hline $\begin{array}{c}\text { KER-1 } \\
\text { Lead-White } \\
\text { Kerameikos } \\
\text { Museum } \\
\text { 4 }^{\text {th }} \text { B.C. }\end{array}$ & $\begin{array}{c}665-687829 \\
1050\end{array}$ & $\begin{array}{c}670 \\
832 \\
1054\end{array}$ & $\begin{array}{l}\text { Cerussite } \\
2 \mathrm{PbCO}_{3}\end{array}$ \\
\hline $\begin{array}{c}\text { PSI-1 } \\
\text { Lead-White } \\
\text { Our reproduction }\end{array}$ & $\begin{array}{c}667 \\
665 \\
687 \\
8291050\end{array}$ & $\begin{array}{c}614 \\
642 \\
990^{*} \\
1102 \\
1140\end{array}$ & $\begin{array}{c}\text { Cerussite, } \\
\text { Hydrocerussite, } \\
\text { Basic } \\
\text { lead(II)carbonate } \\
2 \mathrm{PbCO}_{3} \mathrm{~Pb}(\mathrm{OH})_{2} \\
* 950-1000 \mathrm{~cm}^{-1} \text { may } \\
\text { exist in cerussite, see } \\
\text { text }\end{array}$ \\
\hline
\end{tabular}

Table 3a: Raman vibration bands from Bibliography, bands of the samples KER-1, PSI-1, EGY-1, EGY-2 compared to expected within errors, and mineralogical description.

Table 3a: Bandes de vibration Raman données par la bibliographie, bandes des échantillons KER-1, PSI-1, EGY-1, EGY-2 comparées, et description minéralogique.

\begin{tabular}{|c|c|c|}
\hline Sample code & IRPAS peaks & $\begin{array}{l}\text { Mineralogy } \\
\text { Description }\end{array}$ \\
\hline $\begin{array}{c}\text { EGY-1 } \\
\text { Egyptian-blue from } \\
\text { Kifissia } \\
\text { 4 }^{\text {th }} \text { B.C. }\end{array}$ & $\begin{array}{c}756, \\
979, \\
1033, \\
1157, \\
1488, \\
1604, \\
1666, \\
1774, \\
1874, \\
1982, \\
2854, \\
2923, \\
3386\end{array}$ & $\begin{array}{c}\text { Egyptian blue } \\
\text { calcium } \\
\text { copper(II) silicate, } \\
\mathrm{CaCuSi}_{4} \mathrm{O}_{10}\end{array}$ \\
\hline $\begin{array}{c}\text { EGY-2 } \\
\text { Egyptian blue } \\
\text { Kremer } \\
\text { (modern) }\end{array}$ & $\begin{array}{c}756, \\
979, \\
1033, \\
1157, \\
1604, \\
1670, \\
1774, \\
1870, \\
1982 .\end{array}$ & $\begin{array}{c}\text { Egyptian blue } \\
\text { calcium } \\
\text { copper(II) silicate, } \\
\mathrm{CaCuSi}_{4} \mathrm{O}_{10}\end{array}$ \\
\hline $\begin{array}{c}\text { KER-1 } \\
\text { Lead-White Kerameikos } \\
\text { Museum } \\
\mathbf{4}^{\text {th }} \text { B.C. }\end{array}$ & $\begin{array}{c}679, \\
733, \\
841, \\
995, \\
1049, \\
1427, \\
1736\end{array}$ & $\begin{array}{l}\text { Cerussite } \\
2 \mathrm{PbCO}_{3}\end{array}$ \\
\hline $\begin{array}{c}\text { PSI-1 } \\
\text { Lead-White } \\
\text { Our reproduction }\end{array}$ & $\begin{array}{c}787, \\
879, \\
987, \\
1088, \\
1134, \\
1196, \\
1404, \\
1435, \\
1543, \\
1612\end{array}$ & $\begin{array}{c}\text { Cerussite, } \\
\text { Hydrocerussite, } \\
\text { Basic lead(II) } \\
\text { carbonate } 2 \mathrm{PbCO}_{3} \\
\mathrm{~Pb}(\mathrm{OH})_{2}\end{array}$ \\
\hline
\end{tabular}

Table 3b: IRPAS absorption bands of samples KER-1, PSI-1, EGY-1, EGY-2, and mineralogical description.

Table 3b: Bandes d'absorption IRPAS des échantillons KER-1, PSI-1, $E G Y-1, E G Y-2$ et description minéralogique.

\section{Conclusion}

The analytical techniques of SEM/EDS, XRD, RAMAN, IRPAS were applied on two important $4^{\text {th }}$ century B.C pigments, one from a tablet and the other from a pure blue powder. The importance lied on their relevance to Theophrastus' recipe described in his treatise On Stones, [21] as well as in the successful reproduction in laboratory conditions. Pigment identification was quite effective. The white powder identified as cerussite, though it includes hydrocerussite too, and it is the well known substance of 


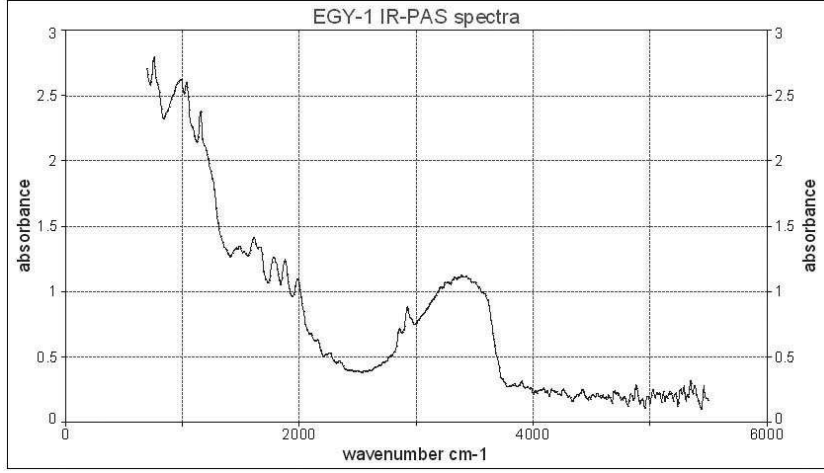

Figure 6a: IR-PAS spectrum of sample EGY-1. Archaeological material from excavation at Kifissia (Attica, Greece) dated to $4^{\text {th }}$ century B.C., contemporary to Theophrastus' Era.

Figure 6a: Spectre IR-PAS de l'échantillon EGY-1. Substance archéologique de la fouille de Kifissia (Attique, Grèce), datée du IV siècle BC, contemporaine de l'époque de Théophraste.

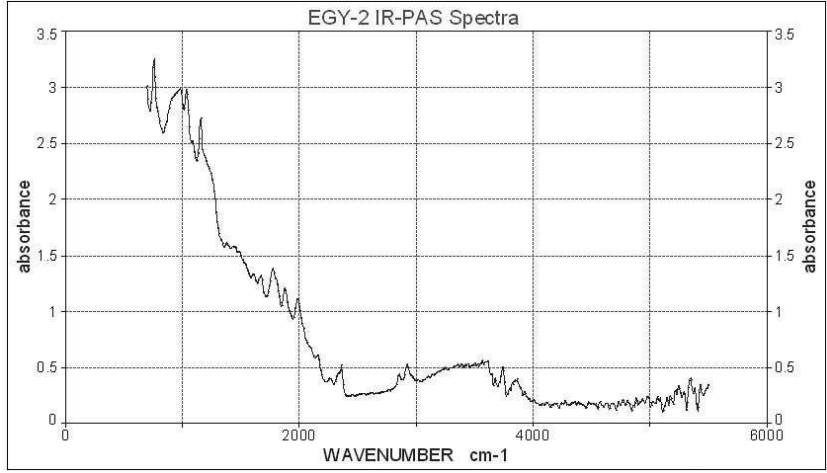

Figure 6b: IR-PAS spectrum of sample EGY-2. Modern reproduction of synthetic Cuprorivaite by Kremer Lab. Co (Germany). Figure 6b: Spectre IR-PAS de l'échantillon EGY-2. Reproduction moderne de Cuprorivaite synthétique par le laboratoire Kremer (Allemagne).

Lead White attributed to Theophrastus' psimythion. The blue colour from Kifissia is identified as the Egyptian blue or Kyanos compared to modern pigment production. The modern reproduction EGY-2 (from Kremer) is surely a most pure state of Egyptian blue as the used compounds are absent of contaminations and thus are chemically free of pollutants. While ancient material could not be made from so pure ingredients as today and this is apparent in their relevant comparison: they are broadly similar and ancient material contains some low quantities of additional compounds. The recipe of Theophrastus for the Lead White (psimithion) production has been reconfirmed with experimental simulation technique by using the clay vessel.

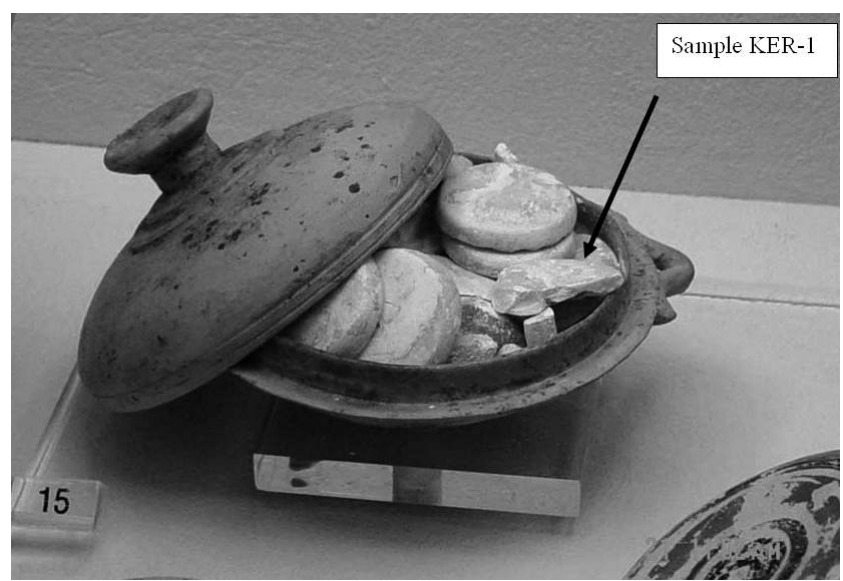

Figure 7: Vessel (Lekanis) with white psimythion from Kerameikos Archaeological Museum at Athens. Sampling is indicated. Figure 7 : Vaisselle (Lekanis) avec du psimythion blanc provenant $d u$ Musée Kerameikos d'Athènes. L'échantillonnage est indiqué.

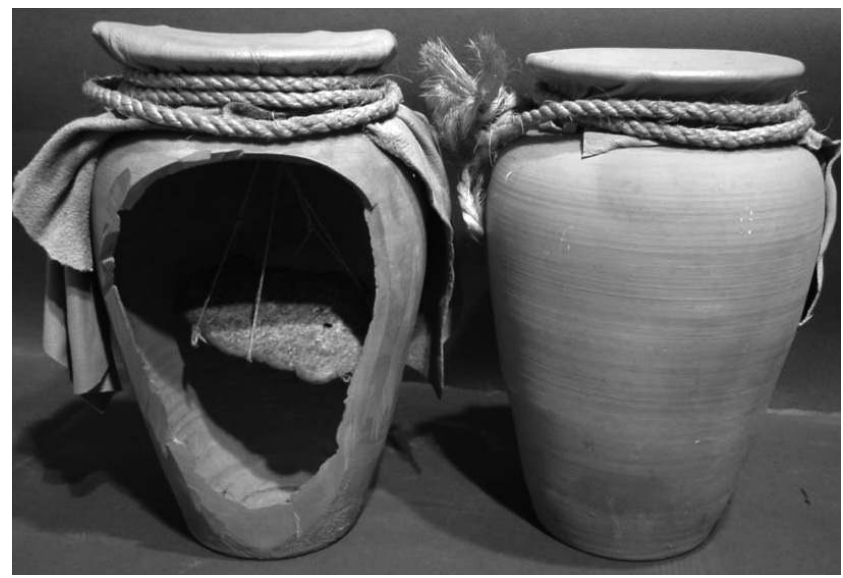

Figure 8: Reconstruction of the apparatus according to Theophrastus in his text "On Stones" for the preparation of the psimythion (lead white).

Figure 8 : Reconstitution de l'appareil selon Theophraste d'après son texte "Des Pierres", pour la préparation du psimythion (Blanc de plomb).

\section{Acknowledgements}

This paper (thesis) is part of the 03ED. 141 research project, with the title: "Chromatology of Theophrastus of Eressos, Identification, Analyses, Abutment in management of Cultural Heritage", implemented within the framework of the "Reinforcement Program of Human Research Manpower" (PENED) and co-financed by National and Community Funds (25\% from the Greek Ministry of Development-General Secretariat of Research and Technology and 75\% from E.U.- 
European Social Fund). We would like to thank the $3^{\text {rd }}$ Ephorate of Prehistoric \& Classical Antiquities of Greece for permission to sample from the Kerameikos Museum at Athens, and the $2^{\text {nd }}$ Ephorate of Prehistoric \& Classical Antiquities of Greece for the sampling of the "unknown blue pigment" from the tomb at Kifissia Archaeological Collection. The authors would like to thank Dr Y.Bassiakos of NCPA Demokritos, Athens, for his assistance in the SEMIEDS analysis and Dr V.Psycharis for his help on the XRD analysis. For Raman spectroscopy the authors thank Mr. Travis Thompson and Dr R.Cox of DeltaNu, and Dr. Chris Stevenson for the IRPAS spectroscopy. We are grateful to Prof. V.Perdikatsis for constructive comments. Last, but not least, we express our gratitude to the Foundation of Mountain Sinai and in particular to His Eminence the Archbishop Damianos of St. Catherine Monastery of Sinai and Raitho, for the economic and continuous support of our research project.

\section{References}

Berrie, B., 2007. Artists' Pigments-A Handbook of Their History and Characteristics, Vol. 4 National Gallery of Art, Oxford University and Archetype press, Washington.

Bruni, S., Cariati, F., Casadio, F. and Toniolo, L., 1999. Spectrochemical characterization by micro-FTIR spectroscopy of blue pigments in different polychrome works of art, Vibrational Spectroscopy 20, 15-25.

Calamiotou, M., Sigandiou, M. and Filippakis, S.E., 1983. 'X-ray analysis of pigments from Pella, Greece', Studies in Conservation 28, 117-121.

Calamiotou, M., Siganidou, M. and Filippakis, S.E., 1983. X-ray analysis of pigments from Pella, Greece. Studies in Conservation, 28, 117-121

Caley E. and Richards J., 1956. Theophrastus On Stones, Ohio Univ. Press.

Delamare, F., 2007. Bleus en poudres. De l'art à l'industrie 5000 ans d'innovation. Mines Paris Presse.

Edreira, M.C., Feliu, M. J., Fernández-Lorenzo, C. and Martín, J., 2003. Spectroscopic study of Egyptian blue mixed with other pigments', Helvetica Chimica Acta, 86,29-49.

EichHolz, D.E., 1965. Theophrastus of Eresos, De Lapidus, Oxford Press.

Feller, R.L., 1986. Artists' Pigments-A Handbook of Their History and Characteristics, Vol. $1^{\text {st }}$ National Gallery of Art, Oxford University press, Washington.

FILIPPAKIs S.E., 1978. Analysis of pigments from Thera. In Thera and the Aegean World, Vol. I, Thera Foundation, London, 599-604.

Filippakis, S.E., Perdikatsis, B. and Assimenos, K., 1979. X-ray analysis of pigments from Vergina, Greece (second tomb). Studies in Conservation, 24, 54-58.
Fotakis, C., Anglos, D., Zafiropoulos, V., Georgiou, S. and TORNARI, V., 2007. Lasers in the preservation of cultural heritage. Principles and applications. Taylor \& Francis, New York.

Gettens, R.J. and Stout, G., 1966. Painting materials. A short Encyclopaedia, Dover publications, New York.

Hatton, G. D., Shortland, A. J. and Tite, M.S., 2008. The production technology of Egyptian blue and green frits from second millennium BC Egypt and Mesopotamia, Journal of Archaeological Science, 35, 1591-1604.

Jaksch, H., Seipel, W., Weiner, K.L. and El Goresy, A., 1983. Egyptian Blue, Cuprorivaite. A Window to Ancient Egyptian Technology, Die Naturwissenschaften, 70, 525-535.

Janseens K. and VAN Grieken, R. (eds.) 2004. Non destructive microanalysis of cultural heritage materials. Comprehensive Analytical Chemistry, Wilson \& Wilson's, Elsevier, Amsterdam, The Netherlands.

KaKoul, I, 2002. Late the Classical and Hellenistic painting techniques and materials: review of the technical literature, Reviews in Conservation, No 3, 56-67

Katsaros, T. and Bassiakos, Y., 2002. The colours of Theophrastus: sources, characterization and application, In Color in Ancient Greece, Tiverios, M.A and Tsiafakis, D.S, (eds), Aristotle University of Thessaloniki \& Lambrakis Research Foundation, Thessaloniki, Greece, 201-209.

LaUtie, C.C., 2001. A Raman studies on surface of artifacts, $\mathrm{La}$ Revue de Metallurgie. 789-793.

LuCas, A. and Harris, J.R., 1962. Ancient Egyptian materials and industries, $4^{\text {th }}$ ed., J. Harris, London.

Martens, W.N., Rintoul, L., Kloprogge, J.T. and Frost, R.L., 2004. Single crystal Raman spectroscopy of cerussite. American Mineralogist, Vol. 89, n 2-3, 352-358.

McClelland, J., Jones, R.W., Luo, S. and Seavenson, L. M., 1993. A practical guide to FTIR Photoacoustic Spectroscopy in Practical Sampling Techniques for Infrared Analysis. P.B. Coleman (ed.). CRC Press, Boca Raton, Florida, Chapter 5.

Pagès-Camagna, S., Colinart, S. and Coupry, C, 1999. Fabrication processes of archaeological Egyptian blue and green pigments enlightened by Raman microscopy and scanning electronic microscopy. Journal of Raman Spectroscopy 30, 313-317.

Pagès-Camagna, S. and Colinart, S. 2003. The Egyptian green pigment: its manufacturing process and links to Egyptian blue, Archaeometry, 45-4, 637-658.

Pagès-Camagna, S. and Colinart, S., 2006. Reply to comments on the article "The Egyptian Green Pigment: Its Manufacturing Process and Links to Egyptian Blue" in Archeometry 45(4), 2003, Archaeometry 48 (4) 710-713.

Perdikatsis, V., Kilikoglou, V, Sotiropoulou, S. and Chryssikopoulou, E., 2000. Physicochemical characterisation of pigments from Theran wall paintings. Proceedings of the 
first International Symposium: The wall paintings of Thera, Thera Foundation, Volume I, 103-129, Athens,

Perdikatsis, V, Maniatis, I and SaAtsoglou-Paliadeli, C., 2002. Characterisation of the pigments and the painting technique used on the Vergina Stelae. In Color in Ancient Greece, Tiverios, M. A \& Tsiafakis, D. S. (eds.), Aristotle University of Thessaloniki \& Lambrakis Research Foundation, Thessaloniki, 245-257.

Riederer, J. 1997. Egyptian blue. In E. West Fitshugh (ed.) Artist's pigment- $A$ handbook of their history and characteristics vol. 3 , 23-40, National Gallery of Art, Oxford University Press. Washington.

Tite, M. S., Bimson, M. and Freestone, I.C., 1982. An examination of the high gloss surface finishes on Greek Attic and Roman Samian wares. Archaeometry 24, 117-126.
Tite, M.S., Bimson, M. and Cowell, M.R., 1987. The technology of Egyptian Blue, Early vitreous materials Occasional Paper, 56, 39-46.

Tiverios, M.A. and Tsiafakis, D.S. (eds.), 2002. Color in Ancient Greece. Aristotle University of Thessaloniki \& Lambraki Research Foundation, Thessaloniki, Greece, 316 p.

Welcomme, E., Walter, P., Van Elslande, E. and Tsoucaris, G., 2006. Investigation of white pigments used as make-up during the Greco-Roman period. Applied Physics A: Materials Science \& Processing, 83-4, 551-556. 
